Снежана М. ПОПОВИЋ* Универзитет у Београду Филолошки факултет
Оригинални научни рад

Примљен: 01. 11. 2017.

Прихваћен: 27. 12. 2017.

\title{
ИЗРАДА И СТРУКТУРА ЧЕШКО-СРПСКОГ ФРАЗЕОЛОШКОГ РЈЕЧНИКА
}

\begin{abstract}
У раду се бавимо преводном фразеографијом разматрајући потребе и изазове савремене српске лексикографије у састављању преводног фразеолошког чешко-српског рјечника. Лексикографија је на првом мјесту примијењена лингвистичка дисциплина, међутим, истовремено је и теоријска јер су потребна истраживања и усавршавања да би савремени рјечници одговарали модерним токовима. Изазови аутора се највише огледају у сакупљању грађе, препознавању јединица фразеолошког система, стандардизацији, одређивању профилисаности рјечника, тражењу еквивалената, организацији рјечничког одјељка, његовом изгледу и информацијама које треба да пружа, било да је ријеч о рјечнику мањег или већег обима. Мишљења смо да у изради једног оваквог рјечника треба спојити традиционалну и модерну лексикографију.

Кључне речи: фразеографија, српски језик, чешки језик, макроструктура и микро-
\end{abstract} структура рјечника.

\section{УВОД}

У раду се бавимо савременом српском лексикографијом, односно једном њеном граном - фразеографијом. У нашем случају преводном фразеографијом јер на основу типа рјечника аутори наилазе на различите изазове у раду. Веза између лексикографије и лексикологије, као и фразеографије и фразеологије је тијесна. Лексикографија је на првом мјесту примијењена лингвистичка дисциплина, међутим, истовремено је и теоријска јер су потребна истраживања и усавршавања да би савремени рјечници одговарали модерним токовима. ${ }^{1}$ Данашњи статус лексикографије као засебне гране примијењене лингвистике омогућава јој да има повратни утицај на обогаћивање

\footnotetext{
${ }^{*}$ s.popovic@fil.bg.ac.rs

1 „Лексикографија је заузета практичним активностима састављања рјечника, проблема који се ту јављају, њихове евалуације и сл. Таква оријентација намеће, наравно, наслањање на лексиколошка истраживања, али и рјешавање бројних сопствених проблема који су у лексикологији ирелевантни (нпр. представљање граматичке информације, алфабетизација, намјена, и сл.), а
} 
лексикологије. ${ }^{2}$ За фразеографију се чак сматра да представља један од оних случајева гдје је пракса ишла испред теорије (Чермак 1995: 117).

На почетку напомињемо да чешко-српски фразеолошки рјечник као такав за сада не постоји у штампаном издању не рачунајући прилог штампаном издању докторске дисертације одбрањене прошле године. Овдје желимо да представимо изазове на које смо наишли радећи на том прилогу. Сматрамо да сличне изазове аутори морају премостити током састављања било којих фразеолошких преводних рјечника мањег и већег обима.

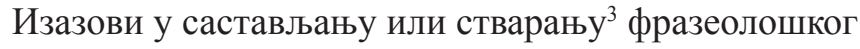 рјечника}

Свакако први задатак у стварању рјечника представља дефинисање његовог типа, садржине и циља. У нашем случају би то био рјечник намијењен стручним преводиоцима и студентима, нарочито оним српским који студирају чешки језик. Међутим, функцијску профилисаност рјечника у овом билатералном језичком односу није нимало једноставно одредити: да ли ће чешко-српски рјечник бити више продуктиван (чеш. kodovaci) за чешке кориснике или рецептиван (чеш. dekódovaci) за српске. Сматрамо да је истовремени квалитет обје функције немогуће постићи, те смо се одлучили да ће на првом мјесту бити рецептиван, декодирајући за говорнике српског језика. На другом мјесту овакав рјечник може имати и посредничку функцију при превођењу текстова са једног на други језик уколико као једносмјеран рјечник има ономасиолошки регистар. Следећи битан елемент у састављању фразеолошког рјечника је одабир јединица, тј. одредница. Ово чини саставни дио макроструктуре рјечника. Врло често се код нас као фразеолошке одреднице појављују само фраземи колокацијског типа, они реченичног се изостављају. Потиче то несумњиво од раније теорије да фраземи нису реченице, коју је заступао Јосип Матешић приликом састављања још увијек најобимнијег фразеолошког рјечника српског и хрватског јези-

који, с друге стране, намећу везе са другим лингвистичким и нелингвистичким дисциплинама" (Шипка 2006: 159).

${ }^{2}$ Потребе модерне српске лексикографије у виду предлога за институционално развијање електронске лексикографије врло је детаљно описао Твртко Прћић у раду Каква нам домаћа лексикографија треба у 21. веку, у коме између осталог наводи и потешкоће са којима се лексикограф може сусрести у вредновању свог рада, као и недоумице које у вези са лексикографијом постоје у друштву: „У том смислу, тврдити паушално, неодмерено и непромишљено да речници нису научни рад, а лексикографија није наука могу само они који никад нису ни чули за озбиљне лексикографске пројекте, а по свој прилици ни имали у руци озбиљан речник, нити се служе озбиљним речницима, јер су очито 'осећајни' или 'мисаони' корисници језика, којима су приручници с таквим богатством података сувишни. Уместо оваквих паушалности треба увидети да неки речници нису наука, а неки речници, они озбиљни, који су резултат озбиљног научноистраживачког рада, неспорно јесу наука, и та се наука зове лексикографија” (Прћић 2016: 238).

${ }^{3}$ Богољуб Станковић је сматрао да је бољи израз стварати него састављати: „Али стварање речника подразумева истраживање које ће претходити раду на речнику, и тећи паралелно са тим радом" (Станковић 1999: 7). 
ка. ${ }^{4}$ Тај став се у савременој фразеологији мијења и опсег ове дисциплине се више не ограничава само на комбинације аутосемантичних ријечи у виду синтагми већ иде од комбинације морфема до цјелина реченичног типа. Наиме, мишљења смо да би требало да се сви они устаљени експресивни спојеви чије значење декодер не може открити на основу значења улазних компоненти нађу у једном таквом рјечнику. Поред дефиниције фразема и дефинисања основне одреднице рјечника, постоји још један аспект везан управо за фразеолошке рјечнике, а то је варијантност фразема. ${ }^{5}$ Као варијанте можемо у чешком језику сматрати: mít néco na krku-mít néco z krku - hodit někomu něco na krk или Tichá voda břehy mele - tichá voda. Варијантност фразема Франтишек Чермак посматра аналогно било којим другим једночланим јединицама деноминације: поменути случајеви се разликују по својој функцији и представљају различите фраземе повезане трансформацијом, варијанта „мора исто као свугдје другдје у лингвистици и језику да остане ограничена на измјени само једне саставнице" (Чермак 2007: 623). Оваква питања стога упућују на важност теорије за праксу, важност идиоматике и фразеологије за фразеографију, али и корекције теорије на основу праксе. За саму идентификацију фразема врло је користан троструки тест који предлаже Чермак, мада напомиње да није уопштен, а који се може упоредити са три сита: 1. тест устаљености, 2. тест аналогије 3. тест неадитивности или незбројивости семантике. Први тест одваја ауторске и ситуационе иновације од фразема, али дозвољава да прођу устаљене дефиниције, стручни аксиоми и сл. Њих одстрањује други тест, који је уједно и тест идиоматичности израза, кроз који се могу провући и вербономинални изрази са апстрактном именицом и други квазифраземи, али ту на сцену ступа трећи тест, којим се провјерава да ли семантика израза представља прости збир значења саставница. Ово нас доводи и до следећег битног питања у стварању рјечника и одабиру саставница: да ли уврстити само фраземе колокацијске структуре или и реченичне и да ли у колокације уврстити комбинације синсемантичних и аутосемантичних ријечи? Узимајући у обзир све наведено, држимо да треба у фразеолошке рјечнике уврштавати фраземе у тзв. „ширем смислу”, те смо са формалне стране сматрали да у чешко-српски фразеолошки рјечник треба да уђу сви фраземи који имају структуру колокација - бинарних и проширених, као и они који имају структуру реченице. ${ }^{6}$

Код мањих фразеолошких рјечника (какав је наш) аутор може наићи на проблем одабира грађе, уколико не жели тематски рјечник а жели да крите-

${ }^{4}$ „Чињеница да фразем није реченица, да он по својој структури није самосталан текст говори о његовој сродности с ријечју и о његову разликовању од типова чврстих веза ријечи реченичнога карактера, као што су на примјер, пословице, крилатице, цитати, називи институција, а дјеломице и такозване ситуативне изреке и термини" (Матешић 1982: VI).

${ }^{5}$ Неки аутори, као нпр. Д. Шипка под варијантношћу разумију више различитих фразеолошких облика са истим значењем, као што су без главе и репа и збрда-здола.

${ }^{6} \mathrm{O}$ колокацијама у фразеологији и оправданости употребе термина говорили смо у реферату Комбинаторика у фразеолошким колокачијама српског и чешког језика представљеном на скупу Асоцијације слависта Полислав у Новом Саду. 
ријум одабира фразема буде објективан, а не субјективан. Идеално би било када бисмо на основу фреквентности фразема у датом језику могли одабрати нпр. хиљаду и по оних најчешћих, међутим, лак и поуздан инструмент за то још немамо. Велики електронски корпуси језика - уравнотежени и прегледни, омогућавају сигурне податке, међутим, сам посао претраживања и добијања релевантних резултата захтијевао би да се у датом корпусу претраже сви фраземи једног језика.

На нивоу макроструктуре рјечника поред наведене функцијске профилисаности рјечника постоје још два процеса који представљају изазов, а то су стандардизација и лематизација грађе. Сама стандардизација у ужем смислу подразумијева: „процес” апстраховања од утицаја дијалеката, професије, старости и других социолингвистички мотивисаних аспеката као што је нпр. комуникативна улога говорника (Чермак 1995: 124). Следи затим деконтекстуализација - издвајање из контекста (parole) и добијање форме са одговарајућом функцијом и значењем у језичком систему (langue).

Поредак одредница или рјечничког чланка у фразеолошким рјечницима бива разноврстан. За најприкладнији принцип редослиједа одредница сматрамо уазбучавање односно сређивање по абецедном реду, без одредничких гнијезда, при чему би обрада и тумачење слиједили само под једном одредницом, као што је то случај нпр. у Матешићевом Фразеолошком рјечнику хрватскога или српскога језика, са једним додатком у циљу још већег економисања простором - фразем би био навођен само једном а корисник би био упућен у самом уводу на начин тражења. Одлучујућу улогу у вези са мјестом фразема у рјечнику би по датом редоследу имале следеће врсте ријечи: именице, глаголи, придјеви, прилози, замјенице и бројеви.

На нивоу микроструктуре рјечника главни изазов представља уређење одредничког одјељка, тј. рјечничког чланка. Овдје треба задовољити неколико карактеристика: окренутост према корисницима, задовољење њихових потреба у виду довољне количине података, лакше сналажење кроз рјечник и економисање простором.

У нашем случају, како смо већ нагласили, ријеч је о мањем рјечнику те смо се, како би били задовољени критеријуми објективности, одлучили за соматске фраземе чешког језика. Чешке соматизме смо ексцерпирали из тада четворотомног Рјечника чешке фразеологије и идиоматике (РЧФИ 2009) ${ }^{7} \mathrm{y}$ који улазе поредбени фраземи, именички, глаголски и реченични фраземи. Еквиваленте на српској страни смо тражили у РСАНУ и РМС, у једнотомном рјечнику српског језика, Матешићевом Фразеолошком рјечнику хрватскога или српскога језика и Фразеолошком речнику српског језика Ђорђа Оташевића. Мада је истраживање чешке и српске фразеологије показало велику сличност у фразеолошком систему, нарочито код соматских фразема, могу се јавити, и на једној и на другој страни, фраземи без одговарајућег еквивалента. Главно питање је шта са таквим фраземима. Мишљења смо да би требало да имају своје мјесто у рјечнику, па макар само са тумачењем и егземплифи-

\footnotetext{
${ }^{7}$ Крајем прошле године је изашао и пети том - Ономасиолошки рјечник.
} 
кацијом. Врло ријетко, али и то је могуће, може се јавити као одговарајући еквивалент тзв. лексикални фразем, као у примјерима празнословач за одредницу velká huba или испичуmypa за vypitej mozek. У оваквом рјечнику, с озбиром на то да се заснива на соматизмима, све одреднице се наводе према првој именици у споју.

Почетни елемент одредничког одјељка је фразем у свом неутралном облику, уколико га има; може се десити да га заступа његов најчешћи облик који је код глагола 3. лице једнине (нпр. Pálísvědí ho to na jazyku; Jde o kejhák.) Након одредничког фразема, тј. у овом случају чешког соматизма, могу слиједити следећи подаци: стилска карактеристика у виду употребне етикете, податак о трансформацији, тумачење на српском језику, еквивалент на српском језику, податак о узусу или поријеклу фразема, егземплификација, синоними и антоними у чешком језику, од којих је тумачење једини обавезан елемент.

Код одредничког фразема и његовог еквивалента у српском језику могу се јавити варијанте двојаког типа: синтагматске и парадигматске, које се обиљежавају на различите начине. Синтагматске се тичу оних „слободних”, тј. изостављивих елемената и стоје у загради, док су парадигматске одвојене косом цртом (нпр. nesahat nékomu ani po kolena/kotníky/pás/ramena; je to (tvrdé) j. kost). Такође контекст у виду акузатива или датива личне замјенице, која се наводи у мушком роду као неутралном облику, треба да буде саставни дио одредничког фразема код кога је обавезан. У рјечнику се такође могу наћи уобичајене трансформације у виду вербализације, номинализације, адјективизације, компаративизације, адвербизације и препозиционализације без скраћенице која би упућивала на врсту трансформације.

\section{Закључак}

Премда на уређење фразеолошког рјечника може сваки његов корисник имати субјективни назор, мишљења смо да сваки овакав рјечник треба:

- д да осликава ситуацију у савременом језику;

- $\quad$ да се ослања на штампане и електронске изворе језика, да узима у обзир да су фраземи карактеристични за књижевни језик и за његове колоквијалне варијанте;

- $\quad$ да се, уколико је то могуће, подреди фреквентности фразема, али да не запостави оне фраземе који се не појављују често;

- $\quad$ да има одредничке одјељке са детаљним информацијама о стилској карактеристици, варијантама, трансформацијама, синонимима и, евентуално, антонимима уз контекст и тумачење;

- $\quad$ егземплификација је у том смислу врло пожељна, даје декодирајући узус, служи активној функцији комуникације за разлику од горенаведених података који остварују њену пасивну функцију;

- одреднице би требало наводити по абецедном реду, једноставно и економично, без груписања у гнијезда и понављања фразема више пута; 
- $\quad$ врло користан додатак нарочито за једнојезичне фразеолошке рјечнике представљају еквиваленти на страним језицима; проналазимо их у РЧФИ, и то на енглеском, њемачком, руском и француском језику, што доприноси његовом богатству.

У циљу осавремењивања фразеографије требало би разматрати електронске верзије штампаних издања или могућност претраживања на интернету у оквиру корпуса савременог језика. Твртко Прћић, објашњавајући термин електронска лексикографија, наводи: „Указујући на медијум у којем се савремена лексикографија највише остварује у пракси, и то у сва четири своја домена, овај термин истовремено одређује и њен теоријско-методолошки идентитет, и њену теоријско-методолошку суштину. С овом околношћу на уму, термини савремена лексикографија и електронска лексикографија овде ће бити изједначени, па свако помињање првог треба разумети у смислу другог - или, обједињено: савремена (е-)лексикографија" (Прћић 2016: 236). Удруживањем снага са рачунарском лингвистиком домаћа лексикографија и фразеографија би се несумњиво уклопиле у модерне токове и приближиле савременом кориснику.

\section{ЛИТЕРАТУРА}

Матешић 1982: J. Matešić, Frazeološki rječnik hrvatskoga ili srpskoga jezika, Zagreb: Školska knjiga.

Прћић 2016: T. Prćić, Kakva nam domaća leksikografija treba u 21. veku, $u$ : S. Gudurić, M. Stefanović (red.), Jezici i kulture u vremenu i prostoru V, Novi Sad: Filozofski fakultet, 231-252.

РЧФИ 2009: F. Čermák, J. Hronek, J. Machač et al., Slovník české frazeologie a idiomatiky $I-I V$, Praha: Leda.

Станковић 1999: Б. Станковић, Лексикографски огледи, Београд: Славистичко друштво Србије.

Чермак 1995: F. Čermák, R. Blatná, J. Filipec et al., Manuál lexikografie, Praha: H\&H.

Чермак 2007: F. Čermák, Idiomatika a frazeologie česká a obecná, Praha: Karolinum.

Шипка 2006: D. Šipka, Osnovi leksikologije i srodnih disciplina, Novi Sad: Matica sprska. 
Snežana M. Popović

\section{CREATING AND STRUCTURE OF THE CZECH-SERBIAN PHRASEOLOGICAL DICTIONARY}

\section{Summary}

In this paper we deal with bilingual phraseography considering the needs and challenges of contemporary Serbian lexicography in the form of the creating of the phraseological Czech-Serbian dictionary. First at all lexicography is an applied linguistic discipline; however, at the same time it is theoretical discipline and it requires research and improvement so that modern dictionaries can fit modern trends. The author's challenges are mostly reflected in the collection of material, the recognition of units of the phraseological system, standardization, and the determination of vocabulary profiles, the search for equivalents, the organization of the dictionary section, its appearance and information to be provided, whether it is a dictionary of a smaller or larger volume. We think that in the creation of such a dictionary, traditional and modern lexicography should be combined.

Key words: phraseography, Serbian language, Czech language, macrostructure and microstructure of the dictionary. 